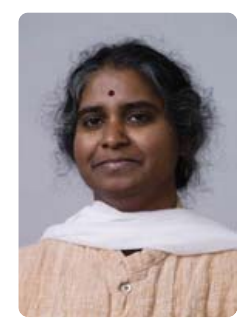

\title{
The road not taken
}

Den nylig etablerte IASP-task force på arbeid og arbeidsplass ledet av Sally Spencer-Thomas, administrerende direktør i Carson J. Spencers stiftelse i USA, har påpekt at potensialet for selvmordsforebygging på arbeidsplassene ikke er fullt utnyttet. De beste og mesteparten av våre våkne timer tilbringer vi på jobben. En stor del av våre beste år tilbringer vi også som arbeidstakere. Det er ikke uvanlig at vi er ved best helse i jobblivet og når høyden av personlig vekst mens vi arbeider. Likevel, det kan være korte perioder hvor man trenger mer omsorg enn det synes som. At man oppsøker og får slik omsorg er en del av det fellesskap og den tillit samfunn er bygd på. I moderne samfunn kan slik omsorg og pleie bli formalisert og institusjonalisert, noe som sikrer at den trengende blir møtt. Selvmordsforebyggende tiltak på arbeidsplassen kan ha ulike former. Nettsiden til IASP viser til flere linker til slike aktuelle tiltak:

http://www.iasp. info/resources/Suicide_and_the_Workplace/

I dette nummeret av Suicidologi ser vi på forskjellige aspekter ved arbeidsrelatert selvmordsatferd. Nummeret dekker et vidt spekter; fra Arne Thorviks artikkel om selvmord som politisk variabel knyttet til arbeid under kommunismen, til hvordan en pasients selvmord kan påvirke terapeuter og leger i to artikler ved Eva Svendsen og Anne Davidsen. Nummeret berører dimensjoner ved selvmordsatferd som ikke nødvendigvis er lett synlige og - kanskje - derfor ikke har blitt forsket mye på.

I dette nummeret av Suicidologi synligjøres noen problemområder vedrørende suicidal atferd og arbeidsliv. Et av problemområdene handler om forandringer i tradisjonelt arbeid, som reindrift, noe som er mye mer enn en jobb og en inntektskilde blant samer i Norge. Dette blir adressert i Anne Silvikens artikkel. Anestesilege Usha Gurunathan har meldt inn sin bekymring i en artikkel som tar for seg anestesilegers tilgang på giftige medikamenter, kombinert med kunnskapen om å bruke dem i fatale doser, under stressende forhold og mangel på fellesskap. I en dansk registerstudie, der 3195 selvmord over 55 yrker var studert, ble en større del av den høyere risikoen for selvmord blant leger og sykepleiere forklart ved høyere bruk av forgiftning som metode, grunnet tilgang på og kunnskap om, gift (Agerbo, Gunnell, Bonde, Mortensen e Nordentoft, 2007). I den samme studien fant man også at psykiatrisk sykdom var knyttet til forholdet mellom selvmord og yrke kun blant leger, kanskje på grunn av et større tap av selvfølelse, og derfor en sterkere følelse av å være stigmatisert.

Enda en tilnærming til arbeidsliv og selvmordsproblematikk i dette nummeret omhandler mangelen på jobbmuligheter for asylsøkere i nye land - mennesker som har blitt tvunget til a forlate sin tidligere jobb under traumatiske forhold - og er skrevet av Nicholas Procter og kolle-ger. Dette nummeret er derfor et fors $ø$ k på å forstå hvordan selvmordsforebygging kan bli bedre tilpasset arbeidslivet gjennom å fokusere på mindre kjente aspekter ved arbeidsrelatert suicidal atferd i Norge og andre steder i verden.

\section{Latha Nrugham,}

gjesteredaktør

References

Agerbo E, Gunnell D, Bonde JP, Mortensen PB e Nordentoft M. 2007. Suicide and occupation: The impact of socio-economic, demographic and psychiatric differences, Psychological Medicine, 37, 1131-1140.

Robert Frost. Title is made of words from the poem 'The Road Not Taken'. Mountain Interval, Henry Holt e Co. 1916

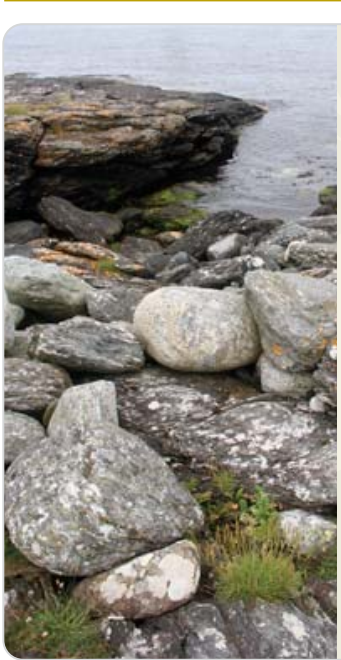

\section{Suicidologi - et fagfellevurdert tidsskrift}

Vi vil takke følgende personer som har vurdert manuskripter for Suicidologi i 2011 :

Jan Beskow

Stian Biong

Jørgen Bramness

Juliet Cohen

Elin Anita Fadum

Elene Fleischer

Gunilla Fosse

Sven Hassler

Erlend Hem
Henning Herrestad

Karsten Hytten

Tordis Sørensen Høifødt

Pravin Israel

Lars Jacobsson

Ildri Kjølseth

Bo Larsson

Steinar Lorentzen

Erlend Mork
Jennifer Muelenkamp

Alexandra Naletova

Merete Nordentoft

Latha Nrugham

Ingeborg Rossow

Reidar Tyssen

Anita Tørmoen

Diana D. van Bergen

Fredrik Walby

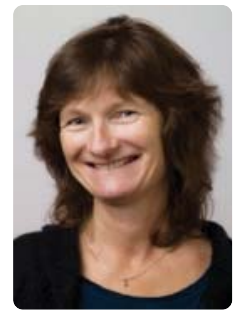

Nytt fra NSSFS Internettsider

Ved

Kirsti Amundsen

Menypunktet Aktuelt -

Selvskading er farlig

Mange av de unge som skader seg selv, $\varnothing$ nsker å slippe unna en uutholdelig følelse. Men selvskading er en kortsiktig løsning, og både farlig og uhensiktsmessig. Ungdom og foreldre som deltar i NSSFs forskningsprosjekt om selvskading, vil lære nye måter å forholde seg til vanskelige følelser på, sier forsker og terapeut Anita Johanna Tørmoen i et intervju. Les mer under Aktuelt.

Menypunkt Formidling - Statistikk

D $\phi$ dsårsaksstatistikken for 2010

ble frigitt 14. oktober 2011.

Totalt antall selvmord var 548:

384 menn og 164 kvinner.

Psykisk helsevern - unaturlige d $\phi$ dsfall Meldinger om uønskede hendelser i spesialisthelsetjenesten (psykisk helsevern). Antall meldinger om dødsfall på grunn av selvpåførte skader har stadig $\varnothing \mathrm{kt}$.

Dette kan tyde på at helsevesenet har blitt bedre til å melde denne type hendelser, skriver Helsetilsynet i rapport $7 / 2011$. Helsetilsynets rapport 1/2011 dekker årene 2001-09 og viser utviklingen over tid.

Se Formidling - Statistikk for mer info.

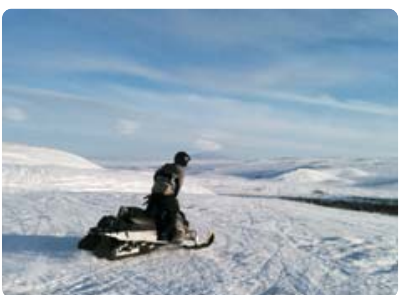

Forsidebildet

Bildet er tatt på vidda ovenfor en samisk bygd som heter Sirbma i Tanadalen. Det gode scooterlivet på vidda - fritt og vilt.

Foto: Anne Silviken 